\title{
ORGANIZATION DEVELOPMENT INTERVENTION TOWARDS EFFECTIVE AND EFFICIENT PERFORMANCE OF THE PRESBYTERIAN UNIVERSITY OF EAST AFRICA (PUEA) KIKUYU CAMPUS, KENYA. EAST AFRICA.
}

\author{
Miriam Wanjiku Gichung'wa ${ }^{1 *}$ \\ *11Miriam Wanjiku Gichung'wa, Email: mwgichungwa@yahoo.com, +254723448496
}

*Corresponding Author: -

Email: mwgichungwa@yahoo.com

\begin{abstract}
: -
This study was on Organization development interventions on the effectiveness and efficiency as a means of increased performance of an organization the case of Presbyterian University of East Africa (PUEA). The research was both descriptive and comparative in nature done in four phases: Assessment of the Organization, OD Interventions, Monitoring and implementation and finally evaluation of the identified problems. The pre and post intervention data was collected from 25 staff who was involved in the study through administering of a 35 questions questionnaire, observation and interviews on specific people. The focus was on VMGS, Structure, Process, People and Technology. The t-test and p-value analysis showed a significance change leading to the rejection of the null hypothesis. The study concluded that the Intervention activities brought about the effective and efficient performance at PUEA. Further, it is an indicator that with the full implementation of the strategic plan, PUEA would achieve optimum performance. Based on the outcome and for continuity and sustainability, the study recommends that all the organizational development intervention activities done in the VMGS, Structure, Process, People and Technology should be institutionalized in the organization practices for increased performance.
\end{abstract}

Keywords: Effective, Efficient Performance, OD Interventions

\section{(c) $(\$)$}




\section{Background of the study}

The Presbyterian Church of East Africa, led to the need for an increased number of teachers. To cater for this demand, the church established Thogoto, Thika, Kambui and TumuTumu Teacher's Training Colleges. After independence in 1963, were converted into girls' secondary schools. Thogoto Teachers' Training Colleges and Thika Teacher Training Colleges, were established in response to the growing need of primary schools for teachers with a Christian foundation. This triggered the realization that other professionals with a Christian foundation were needed. In responding to this need, the $12^{\text {th }}$ PCEA General Assembly resolved to establish a University (Resolution 2093, April 1988) and formed a Steering Committee to develop a University proposal. The PCEA allocated 100 acres of land at Thogoto Mission Centre and raised funds from its congregations and well-wishers for the development of the proposed university. The construction of the first administration building and teaching blocks were put up over a number of years. In 2007 , the University was given a letter of Interim Authority to start a University by the Commission for Higher Education. The university admitted its first degree student in 2008.

In addition to its commitment to education, PCEA developed health facilities to meet health care needs in the community. In 1906, the first permanent hospital in Central Region of Kenya was established at Thogoto Mission Centre. In 1914 it was named The Hunter Memorial Hospital in memory of sponsor, Mrs. R. J. Hunter's husband. The hospital was later renamed Kikuyu Mission Hospital. The missionaries started a second hospital at TumuTumu in 1910 in Nyeri District, followed, in 1922, by a third hospital at Chogoria in Meru District.

The now well-established hospitals at Kikuyu, TumuTumu in Nyeri and Chogoria in Meru are being used by Universities (Presbyterian University of East Africa, Jomo Kenyatta University of Agriculture and Technology) as Teaching Hospitals for their health professionals. The hospitals and clinics give the Presbyterian University of East Africa a significant niche in the training of health professionals in East Africa and beyond where the Church has wellestablished hospitals and clinics. As a result, the University can provide many educational opportunities for students from East Africa and beyond. (Kenya’s Healthy policy. November 1994, Government of Kenya, strategic plan 2012)

\section{Christian Identity}

The Presbyterian University of East Africa (PUEA) offers educational programs founded on the values of Christian transformational education, research, professional integrity, self-reliance and service to God and humanity. The University is a Christ-centered institution, serving all with equity, regardless of ethnicity, creed or culture, safeguarding human and gender rights. The University aspires to anchor its motto, "finding new paths" (Jeremiah 6:16), in its values of academic excellence, responsible freedom of thought, selfless service, value addition to life, respect for self and others, accountability, self-reliance, discipline, truth, integrity, honesty, justice, tolerance, transparency, and fair play. The University will continue to build on the four pillars of the Presbyterian Church of East Africa namely: Pillar 1: Evangelism through its Churches, Pillar 2: Education for all through its schools, colleges and this University, Pillar 3: Health for all through its hospitals and health centres, and Pillar 4: Community service through its community centres.

PUEA was faced by a number of problems including stagnation due to lack of finances that brings about growth and expansion and hence the need to employ the OD process in order to be specific on problem identification and implementation of any possible strategies.

The researcher employed Susman and Evered (1978) five step research process cycle: Diagnosing, Action planning, Action taking, Evaluating and specifying learning. A pre-intervention assessment was conducted based on five elements: VMGS, Structure, Process, People and Technology.

The initial investigation was through an Organization analysis, SWOT analysis, and later an in-depth problem analysis through administering a detailed questionnaire covering the five elements. Some of the key problems that were identified included: lack of a clear vision, Mission, Goals, and strategies; Unclear organization structure, Lack a communication structure, Lack of key policies, Insufficient funds for running the organization, poor leadership style, high staff turnover, low enrolment by students, poor organizational image, lack of internal control systems, lack of physical security, poor utilization of available resources, poor IT connectivity, Technology

or computer illiteracy. All these problems were grouped and the five elements and subjected to an in-depth analysis forming the basis for generating OD interventions. The interventions focused on developments of new vision, mission, goals, strategies; new organizational structure, new communication structure and a number of policies covering areas that were problematic.

\section{Objectives}

The study aimed to assess the effectiveness and efficient performance of The Presbyterian University of East Africa. Specifically, the study aimed to answer the following questions: (1) what are the pre- intervention assessment and post intervention of PUEA in terms of: Vision, Mission, Goals and strategies (VMGS), Structure, Process, People, and Technology. (2) Are there significant differences in the pre-intervention and post intervention data? And (3) what are the transformation indicators?

To answer these questions, the researcher had to assess the following elements:

(a) Vision, Mission, Goals and strategies (VMGS), (b)Structure, (c) Process, (d) People, and (d)Technology. Also whether there was significant differences between the pre-intervention and post intervention data and finally come up with the transformation indicators. 


\section{The Hypothesis}

There are no significant differences between the pre and post intervention data on the five elements.

\section{Scope and Limitation}

This study focused on the Development of Interventions on the 5 elements of PUEA for effectiveness a $\mathrm{n} d$ efficiency of its operations towards improved organizational performance. The study involved 25 people respondents who were also the ratters.

\section{Limitations}

Accuracy and honesty of the respondents was determined by data reliability and validity since it was within PUEA. A period of seven-month Time may not been sufficient to observe change and improvement.

\section{Methodology}

This study assumed the descriptive and comparative research designs. Descriptive design was useful in establishing a general overview of the problem situation at PUEA. Face to face interviews with managers, review of organizational documents, survey feedback and focus group discussions were used to gain an overview of the problem. The comparative design was used to evaluate the pre and post- intervention data.

25 staff members drawn from across all the University departments were involved. They were directly involved in pre and post intervention surveys as well as in the OD interventions.

Pre and intervention post intervention assessment data was collected using through a detailed questionnaire. Data obtained was keyed into excel spread sheets and analyzed using mean scores which were used to determine both the tvalue and the p-values.

\section{Data Processing and Analysis}

The mean score for both pre and post- interventions were subjected to a statistical data treatment, t-test and $\mathrm{p}-$ determined at the significant level of $\mathrm{a}=0.05$ for determining whether to accept or reject the hypothesis.

\section{Results}

The table below shows a Comparison summary of the pre and post Intervention Data

Table 3 presents the comparison between the pre-intervention means and the post-intervention means of the vision, mission, goals and strategies of PUEA.

Table 3: Pre and Post ODI on Vision, Mission, Goal, Strategies (VMG)

\begin{tabular}{|c|c|c|c|c|c|c|c|}
\hline \multirow{2}{*}{$\begin{array}{l}\mathrm{N} \\
\mathrm{o}\end{array}$} & \multirow[t]{2}{*}{ Items } & \multicolumn{4}{|c|}{ Pre-intervention } & Post Intervention & \multirow{2}{*}{\begin{tabular}{|c|}
\multicolumn{2}{c}{ Mean } \\
Difference \\
Table 3
\end{tabular}} \\
\hline & & Mean & $\begin{array}{l}\text { Interp } \\
\text { retatio } \\
\text { n. }\end{array}$ & Mean & $\begin{array}{c}\text { Interp } \\
\text { retatio } \\
\mathrm{n}\end{array}$ & & \\
\hline 1 & $\begin{array}{l}\text { Vision and } \\
\text { Missions } \\
\text { Statements are } \\
\text { clear }\end{array}$ & 3.4 & Good & 5.00 & $\begin{array}{l}\text { Very } \\
\text { good }\end{array}$ & 1.6 & \\
\hline 2 & $\begin{array}{l}\text { Goals and } \\
\text { strategies are } \\
\text { clear and } \\
\text { individuals are } \\
\text { able to prioritize } \\
\text { them. }\end{array}$ & 3.0 & Fair & 4.7 & $\begin{array}{l}\text { Very } \\
\text { good }\end{array}$ & 1.9 & \\
\hline 3 & $\begin{array}{l}\text { Organization } \\
\text { vision and } \\
\text { mission are } \\
\text { written and } \\
\text { available to all } \\
\text { and workers are } \\
\text { able to interpret } \\
\text { them. }\end{array}$ & 3.3 & Fair & 4.9 & $\begin{array}{l}\text { Very } \\
\text { good }\end{array}$ & 1.6 & \\
\hline 4 & $\begin{array}{l}\text { Strategic plans } \\
\text { are implemented } \\
\text { in good time. }\end{array}$ & 3.4 & Good & 4.3 & $\begin{array}{l}\text { Very } \\
\text { good }\end{array}$ & .90 & \\
\hline 5 & $\begin{array}{l}\text { Accreditation of } \\
\text { some academic } \\
\text { programs by } \\
\text { CUE is } \\
\text { independent with } \\
\text { strategic plans } \\
\text { implementation. }\end{array}$ & 3.4 & Good & 4.6 & $\begin{array}{l}\text { Very } \\
\text { good }\end{array}$ & 1.2 & \\
\hline & Overall Mean & 3.3 & Fair & 4.7 & $\begin{array}{l}\text { Very } \\
\text { good }\end{array}$ & 1.4 & \\
\hline
\end{tabular}


Table reveals that there is improvement and commitment to the vision, mission, goals and strategies which led to the overall rating to move from (3.3) to (4.7) from fair to very good. This confirms: Fred R. (2007) states that a clear organization vision focuses, directs, motivates, unifies and excites business into superior performance; Pearce \& Robinson (2005), states that an explicit mission statement should address the expectation of all stakeholders for the company's performance in the long-run.

Table 4 below shows the comparison between the pre-intervention and the post intervention of the organizational structure.

Table 4: Pre and Post ODI Mean Rating on Structure

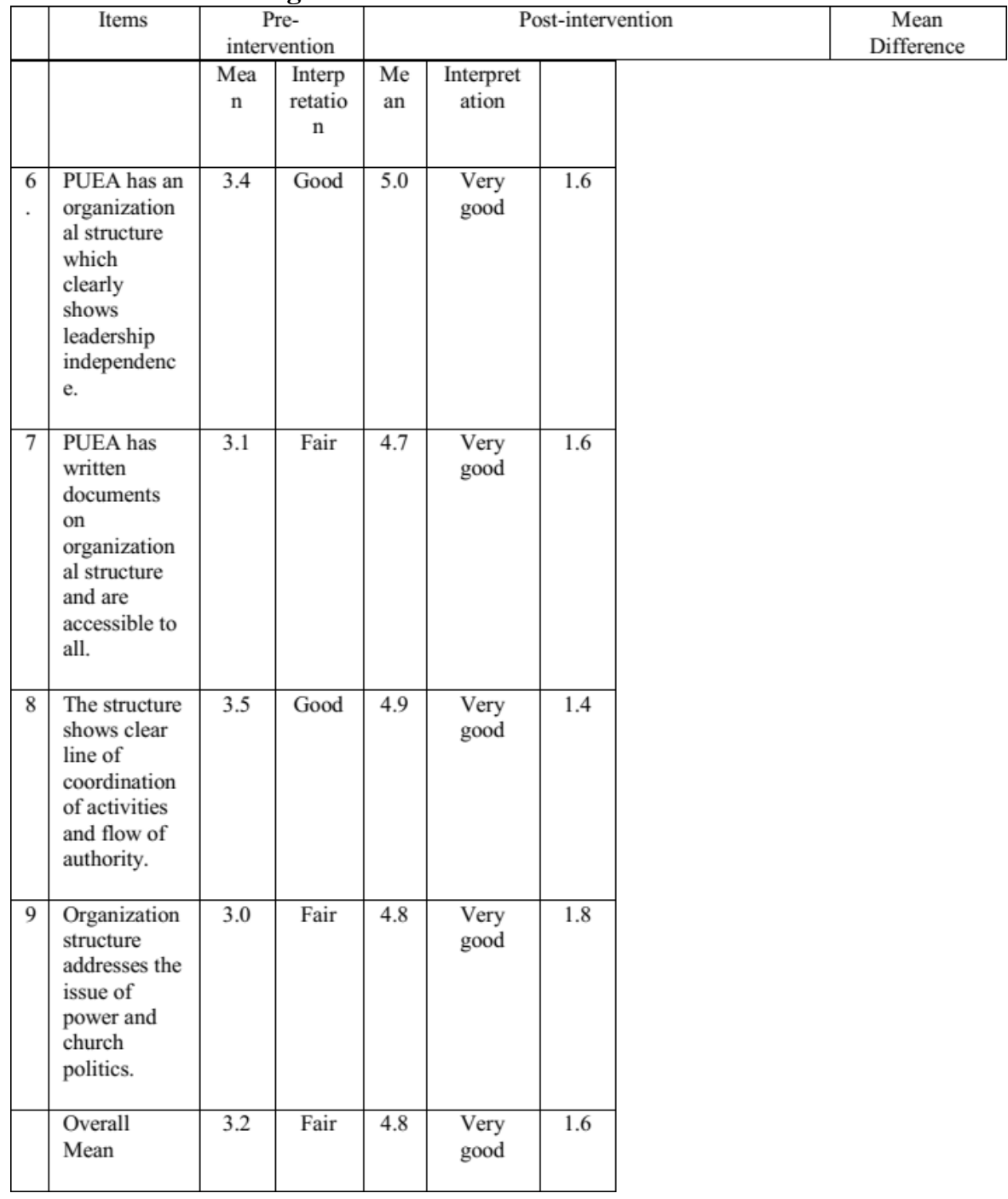

The mean rating on structure has improved from 3.2 to 4.8 . This is interpreted as fair to very good. According to Silberman, (2003), in order for an organization to achieve effectiveness in its operations, there is needed to develop an appropriate organization 
Table 5 below presents the data which are the mean ratings on process before and after ODI

Table 5: Pre and Post ODI Mean Rating on Process

\begin{tabular}{|c|c|c|c|c|c|c|}
\hline & \multirow[t]{2}{*}{ Items } & \multicolumn{2}{|c|}{ Pre-intervention } & \multicolumn{2}{|c|}{ Post-intervention } & \multirow{2}{*}{$\begin{array}{c}\text { Mean } \\
\text { Difference } \\
\end{array}$} \\
\hline & & Mean & $\begin{array}{c}\text { Interpretat } \\
\text { ion }\end{array}$ & Mean & Interpretation & \\
\hline 10 & $\begin{array}{l}\text { The organization has } \\
\text { sufficient support } \\
\text { systems. }\end{array}$ & 2.9 & Fair & 3.5 & Good & 0.6 \\
\hline 11 & $\begin{array}{l}\text { Existing Internal control } \\
\text { systems contribute to } \\
\text { financial } \\
\text { mismanagement. }\end{array}$ & 3.2 & Fair & 4.0 & Good & 0.8 \\
\hline 12 & $\begin{array}{l}\text { Communication systems } \\
\text { at PUEA have effects on } \\
\text { feedback. }\end{array}$ & 1.7 & Very poor & 3.5 & Good & 1.8 \\
\hline 13 & $\begin{array}{l}\text { Performance evaluation } \\
\text { and the reward systems } \\
\text { are adequate and good. }\end{array}$ & 1.9 & Poor & 3.7 & Good & 1.6 \\
\hline 14 & $\begin{array}{l}\text { Existing marketing } \\
\text { strategy has effects on } \\
\text { student reduction. }\end{array}$ & 2.1 & Poor & 3.2 & Fair & 1.1 \\
\hline 15 & $\begin{array}{l}\text { Current accounting } \\
\text { practices and annual } \\
\text { financial reports affects } \\
\text { decision making. }\end{array}$ & 1.9 & Poor & 3.8 & Good & 1.9 \\
\hline 16 & $\begin{array}{l}\text { PUEA has sufficient } \\
\text { funds to facilitate } \\
\text { meeting obligations when } \\
\text { they fall due. }\end{array}$ & 1.7 & Very poor & 3.5 & Good & 1.8 \\
\hline 17 & $\begin{array}{l}\text { Exam remittances have } \\
\text { no effects on result } \\
\text { moderation. }\end{array}$ & 2.5 & Poor & 3.4 & Good & 0.9 \\
\hline & Overall Mean & 2.2 & Poor & 3.6 & Good & 1.4 \\
\hline
\end{tabular}

Based on the above table, the University processes improved from a rating of 2.2 to 3.6. The interpretation is from Poor to Good. Confirms that process change is driven by changes on the organizational structure since the two are inseparable 1 and hence depend on each other, (Harigopal, 2006, p.109)

Table 6 below represents the date rating on people before and after the ODI assessments.

Table 6: Pre and Post ODI Mean Rating on People

\begin{tabular}{|l|l|l|l|l|l|l|l|}
\hline & Items & \multicolumn{2}{l|}{ Pre- Intervention } & \multicolumn{2}{l|}{ Post-Intervention } & Difference \\
\hline & & \multicolumn{2}{|l|}{ Mean } & Interpretation & \multicolumn{1}{l|}{ Mean } & Interpretation & \\
\hline 18 & $\begin{array}{l}\text { Informal groups within the } \\
\text { University are extensive }\end{array}$ & 1.7 & Very-poor & 4.5 & Very-poor & 2.8 \\
\hline 19 & $\begin{array}{l}\text { Informal groupings provide } \\
\text { wholesome work environment. }\end{array}$ & 1.3 & Very-poor & 3.8 & Good & 2.5 \\
\hline $\begin{array}{l}\text { Publicity by former employees } \\
\text { has effects on student } \\
\text { enrolment }\end{array}$ & 1.7 & $\begin{array}{l}\text { Very } \\
\text { poor }\end{array}$ & 4.1 & Good & 2.4 \\
\hline 22 & $\begin{array}{l}\text { Workers at PUEA are } \\
\text { complacent with the status quo. }\end{array}$ & 1.9 & Poor & 3.5 & Good & 2.6 \\
\hline 24 & $\begin{array}{l}\text { Student migration is due to own } \\
\text { individual decision. }\end{array}$ & 1.5 & $\begin{array}{l}\text { Very } \\
\text { poor }\end{array}$ & 3.5 & Good & 2.0 \\
\hline $\begin{array}{l}\text { In-service training towards } \\
\text { enabling staff to be effective } \\
\text { team workers is satisfactory. }\end{array}$ & 1.4 & $\begin{array}{l}\text { Very } \\
\text { poor }\end{array}$ & 4.5 & $\begin{array}{l}\text { Very } \\
\text { good }\end{array}$ & 3.1 \\
\hline 26 & $\begin{array}{l}\text { Employees are generally } \\
\text { hardworking and honest in } \\
\text { their jobs. }\end{array}$ & 2.5 & Poor & 4.0 & Good & 1.5 \\
\hline $\begin{array}{l}\text { Employees show high } \\
\text { level of Commitment }\end{array}$ & $\begin{array}{l}\text { Overall } \\
\text { Mean }\end{array}$ & $\mathbf{1 . 5}$ & $\begin{array}{l}\text { Very } \\
\text { poor }\end{array}$ & $\mathbf{4 . 0}$ & Good & $\mathbf{2 . 5}$ \\
\hline
\end{tabular}


Table 7 below represents data rating on Technology before and after ODI assessment.

Table 7: Pre and Post ODI Mean Rating on Technology

\begin{tabular}{|c|c|c|c|c|c|c|}
\hline & Item & \multicolumn{2}{|c|}{\begin{tabular}{|l|l} 
Pre-Intervention & \\
\end{tabular}} & \multicolumn{2}{|c|}{ Post-Intervention } & Difference \\
\hline & & Mean & Interpretation & Mean & Interpretation & \\
\hline 27 & $\begin{array}{l}\text { Tools, equipment and machinery } \\
\text { used at PUEA facilitate speed and } \\
\text { accurate services. }\end{array}$ & $\begin{array}{l}\mathrm{y} \\
\mathrm{d}\end{array}$ & Good & 4.5 & Very good & .9 \\
\hline 28 & $\begin{array}{l}\text { The ICT labs are adequately } \\
\text { computerized, spacious for all } \\
\text { students to be served. }\end{array}$ & $\begin{array}{l} \\
11\end{array}$ & Fair & 4.2 & Very good & .8 \\
\hline 29 & $\begin{array}{l}\text { The physical arrangements at the } \\
\text { workplace are adequately conducive } \\
\text { for productivity }\end{array}$ & e & Fair & 3.5 & Good & .5 \\
\hline 30 & $\begin{array}{l}\text { The physical arrangements } \\
\text { contribute to effective team work. }\end{array}$ & 3.0 & Fair & 3.5 & Good & .5 \\
\hline 31 & $\begin{array}{l}\text { In service training skills in } \\
\text { equipment usage affects machine } \\
\text { utilization. }\end{array}$ & n & Fair & 3.8 & Good & .8 \\
\hline 32 & 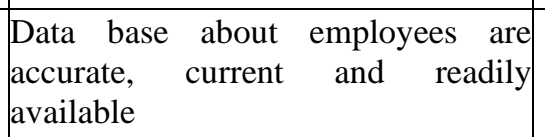 & e & Fair & 4.0 & Good & .8 \\
\hline 33 & $\begin{array}{l}\text { Computer illiteracy affects computer } \\
\text { usage by support staff. }\end{array}$ & $\mathrm{er}$ & Fair & 3.5 & Good & .7 \\
\hline 34 & $\begin{array}{l}\text { LAN coverage at PUEA serves all } \\
\text { staff. }\end{array}$ & 2.5 & Poor & 3.0 & Fair & .5 \\
\hline 35 & $\begin{array}{l}\text { Employees are provided with } \\
\text { adequate tools and equipment for } \\
\text { performing their work well }\end{array}$ & $\mathrm{h}$ & Fair & 3.8 & Good & .5 \\
\hline & Overall Mean & 3.1 & Fair & 3.7 & Goo d & .6 \\
\hline
\end{tabular}


Comparison summary of the pre and post Intervention Data

\begin{tabular}{|c|c|c|c|c|c|c|c|c|c|}
\hline \multirow[t]{2}{*}{$\begin{array}{l}\text { Element } \\
\mathrm{s}\end{array}$} & \multicolumn{2}{|c|}{$\begin{array}{l}\text { Pre- } \\
\text { intervention }\end{array}$} & \multicolumn{2}{|c|}{$\begin{array}{l}\text { Post- } \\
\text { intervention }\end{array}$} & \multirow{2}{*}{$\begin{array}{l}\text { Dif } \\
\text { fer } \\
\text { enc } \\
\text { es }\end{array}$} & \multicolumn{4}{|c|}{ Interpretation } \\
\hline & $\begin{array}{l}\mathrm{Me} \\
\text { an }\end{array}$ & $\begin{array}{l}\text { Inter } \\
\text { preta } \\
\text { tion }\end{array}$ & $\begin{array}{l}\text { Mea } \\
n\end{array}$ & $\begin{array}{l}\text { Interp } \\
\text { retatio } \\
\mathrm{n}\end{array}$ & & $\begin{array}{l}\text { t- } \\
\text { valu } \\
\text { e }\end{array}$ & $\begin{array}{l}\text { p- } \\
\text { valu } \\
\mathrm{e}\end{array}$ & $\begin{array}{l}\text { Ho- } \\
\text { Deci } \\
\text { sion } \\
\text { at } \\
a=0 . \\
05\end{array}$ & $\begin{array}{l}\text { Data } \\
\text { interpre } \\
\text { tation }\end{array}$ \\
\hline $\begin{array}{l}\text { Vision, } \\
\text { Mission, } \\
\text { Goals, }\end{array}$ & 3.3 & Fair & 4.7 & $\begin{array}{l}\text { Very } \\
\text { Good }\end{array}$ & 1.4 & 8.90 & $\begin{array}{l}0.00 \\
1\end{array}$ & $\begin{array}{l}\text { Reje } \\
\text { ct }\end{array}$ & $\begin{array}{l}\text { Signifi } \\
\text { cant }\end{array}$ \\
\hline $\begin{array}{l}\text { Organiza } \\
\text { tional } \\
\text { Structure }\end{array}$ & 3.2 & Fair & 4.8 & $\begin{array}{l}\text { Very } \\
\text { good }\end{array}$ & 1.6 & $\begin{array}{l}19.0 \\
8\end{array}$ & $\begin{array}{l}0.00 \\
0\end{array}$ & $\begin{array}{l}\text { Reje } \\
\text { ct }\end{array}$ & $\begin{array}{l}\text { Signifi } \\
\text { cant }\end{array}$ \\
\hline Process & 2.2 & Poor & 3.6 & Good & 1.4 & 7.01 & $\begin{array}{l}0.00 \\
0\end{array}$ & $\begin{array}{l}\text { Reje } \\
\text { ct }\end{array}$ & $\begin{array}{l}\text { Signifi } \\
\text { cant }\end{array}$ \\
\hline People & 1.5 & $\begin{array}{l}\text { Very } \\
\text { Poor }\end{array}$ & 4.0 & Good & 2.5 & $\begin{array}{l}12.2 \\
8\end{array}$ & $\begin{array}{l}0.00 \\
0\end{array}$ & $\begin{array}{l}\text { Reje } \\
\text { ct }\end{array}$ & $\begin{array}{l}\text { Signifi } \\
\text { cant }\end{array}$ \\
\hline $\begin{array}{l}\text { Technol } \\
\text { ogy }\end{array}$ & 3.0 & Fair & 3.7 & Good & .7 & $\begin{array}{l}12.0 \\
6\end{array}$ & $\begin{array}{l}0.00 \\
0\end{array}$ & $\begin{array}{l}\text { Reje } \\
\text { ct }\end{array}$ & $\begin{array}{l}\text { Signifi } \\
\text { cant }\end{array}$ \\
\hline $\begin{array}{l}\text { Over-all } \\
\text { Average }\end{array}$ & 2.7 & Fair & 4.1 & Good & 1.4 & & & & \\
\hline
\end{tabular}

\section{Discussion}

Table above shows the results of the profile of the pre and post ODI. The P-values obtained in the five areas were all below 0.05 , hence showing significant differences at alpha level of 0.05 . On the basis of the above outcomes, the null hypothesis was rejected as there was confirmation that the OD interventions had a significant impact in the transformation of the performance indicators at the Presbyterian University of East Africa (PUEA)

\section{Vision, Mission and Goals}

The profile on the ratings on VMGs showed a marked improvement from 3.3 (fair to 4.65 (Very good). A t value of 8.90 and $\mathrm{p}$ - value of 0.001 were obtained at level of significance 0.05 . This suggests that there was a significant difference between the ratings obtained during the pre and post ODI assessments and the null hypothesis was rejected. This significant result was as a result of the many participants' involvements in developing the new vision, Mission and Goals of the University. Different groups were volved in the consultation at different and ve their honesty opinion.

\section{Structure}

The profile on the rating on structure showed a remarkable improvement as well from 3.2 (fair) to 4.8 (Very good). A tvalue of 19.08 and a p-value of 0.000 were obtained at the significant level 0.05 . The p-value was below

0.05 and the null hypothesis was rejected as there was a significant difference between the rating of pre and post ODI assessments on the organizational structure.

This was as a result of many staff involved including the ICT department; a continuous review was done to in-cooperate different views.

\section{Process}

The profile on the ratings on the process showed a marked improvement from 2.2 (fair) to 3.575 (good). A value 7.01 and $\mathrm{p}$-value

0.00 were obtained at the significant level (alpha) 0.05 . The p- value was below 0.05 confirming that there was a significance difference between the ratings obtained during the pre and post ODI assessments and the null hypothesis was rejected. The change was brought about by the introduction of different policies, activities, programs while improving on the existing rules and procedures of the various aspects of the University.

\section{People}

The profile rating of people showed an improvement from 1.5 (Very poor) to 3.96 (good). A t-value of 12.28 and pvalue 0.00 were obtained at significant (alpha) level 0.05. The p-value was below 0.05 indicating that there was a significant different between the ratings obtained during the pre and posts ODI assessments on people and the null 
hypothesis was rejected. This kind of change is attributed to the different kinds of involvement of the different stakeholders. The most significant was the involvement of the neighbors of the University including learning institutions and community at large. The University organized for a University day where different learning Institutions and groups were invited on a Sunday morning. Under the University Librarian, books were given to the learning institutions which were a great boost to the University marketing. New key University staffs were employed who became a key input to the increased people participation.

\section{Technology}

In the area of technology, there was a significant change as well from 3.0 (fair) to 3.7 (good). A t-value of 12.06 and pvalues 0.000 were obtained at the significant (alpha) level 0.05 . The p-value was below 0.05 evident that there was a significant difference between the ratings obtained during the pre and post ODI assessments and the hull hypothesis was rejected. The change can be attributed to the collaboration with the google through the google ups training where staff, lecturers and the staff were trained and the training is on-going. Besides this training, many have been exposed to the ICT activities, higher computerization, introduction of the modern technologies in handling processes such as record keeping, on line registration and accessible University services.

Graph 1 below gives a summary on comparison between pre and post ODI assessments on VMGs, Structure, Process, People and Technology

\section{Conclusion}

Based on the OD Interventions, the five elements had improved tremendously.

\section{Recommendation}

In view of the positive results, the OD Interventions should be made institutionalized and should be frequent for continuity and sustainability.

\section{Bibliography \\ BOOKS}

[1].Abbott, A. (1991). A primer on sequence methods: Organization Science, 1(4),375-392.

[2].Abbott, A. (1992). From Causes to Events. Notes on Narrative Positivism:Sociological Methods and Research, 20(4), 428-455.

[3].Anderson D. L. (2010). Organization Development. The process of leading Organizational change. Thousand OAKs: Sage.

[4].Anderson D.L. (2010). Beyond change Management. How to achieve Break through results through conscious change leadership. San Francisco: Pfeiffer.

[5].Argyris, Chris, Schion, Donald A. (1996, 1970). Organizational Learning Theory.

[6].Methods and Practice, New york: Addison Wesley Publishing Company.

[7].Brian T. Pentland, Charles S. Osborn, George Wyner, Fred Luconi. (1999). Useful Descriptions of Organizational Processes: Collecting Data for the Process Handbook.

[8].Bhargava, s. (2003). Transformational leadership. Value-based Management for Indian Organizations: Sage Publications. New Delhi.

[9].Bernard Marr. (2012). Key Performance Indicators: FT Publishing. Financial Times.

[10]. Cameron K.S \& Quinn, R.E. (2011). Diagnosis and changing Organizational Culture. Based on the Competing values Framework. San Francisco: Jossey-Bass.

[11]. Commings \& Worley. (2005). Handbook for Organization Development. Los Angeles. Califonia: Sage Publications.

[12]. Cummings \& Worley. (2008). Organization Development \& Change united $8^{\text {th }}$ ed: US Southern Western College Publishing. Thomson Learning.

[13]. Cumming, T. G. \& Worley C. G. (2009). Organizationa Development and Change. Natorp Boulevart: Cengage.

[14]. Curtis, B., Kellner, M. I., \& Over, J. (1992).Process Modelling. Communications of the ACM, 35(9), 75-90.

[15]. C. Laundo and Jane Laudon. (2000). Information Management. Heather Cummings (Eds.), Research in Organizational Behavior (Vol. 2, pp. 3-43): Greenwich.

[16]. Dawson, Patrick. (2003). Understanding Organizational Change. The contemporary Experience of people at work. Thousand Oaks. Ca: Sage Publications.

[17]. Dessein, Gregory G., Lumpkin, G. T., \& Taylor, Marilyn L. (2005). Strategic Management: Creating Competitive Advantages. New York, USA: McGraw-Hill.

[18]. Dhar and Santosh. (2002). Introduction to organizational Behavior: Excel Books. New Delhi.

[19]. Duxbury, L, \& Higgins. (2003). Work-life conflict in Canada in the new millennium: A status report. Retrieved from http//www. Phac.aspc.gc.ac Publicat/work-travail/report2/index- eng.php

[20]. Drucker, Peter F. (2002). Managing the next Society. New York.: Truman Tailley Books st. Martiris Press.

[21]. David Nadler. (1977, 2000). Organization Development and Change: South-Western College.

[22]. Edward E. Lawler 111. (2006). Organizational Effectiveness: Stanford Press

[23]. Edgar H. Schein. (1997). Organizational Culture \& Leadership: Berrett-Koehler

[24]. Publishers.Fred Luthians. (1992). Organization Behaviour $6^{\text {th }}$ edition: McGraw Hill.

[25]. Fred R. David. (2007). Strategic Management. Concepts and Cases. $11^{\text {th }}$ ed: Prentice-hall, India. 
[26]. French, Wendell L., Bell Cecil Jr. H., \& Zawacki, Robert A. (1994). Organization

[27]. Development and Transformation. 4 ed. San Francisco California. Irwin: McGraw-Hill.

[28]. French, Bell, Zawacki. (2000). Organizational Development and Transformation. California. Irwin: Mcgraw-Hill. Gerald I. Susman \& Evered. (1978, 1983).

[29]. "Action Research" A sociotechnical Systems Perspective” . G. Mprgan. London: Sage Publications.

[30]. Hammer, M. and Champy, J. (1993). Reengineering the Corporation. A Manifesto for Business Revolution. New York: HarperCollins.

[31]. Harigopal K. (2006). Management of Organizational Change-Leveraging Transformation. $2^{\text {nd }}$ ed: Sage Publications. New Delhi.

[32]. Harold J. Leavitt. (2007). Management: New York Times Hill, Michael A., Ireland, R. Duane., \& Hoskisson, Robert E. (2005). Strategic Management. Competitiveness and Globalization Concepts. United States: Thomson South-Western.

[33]. Hill, Charles W. L., Johnes Gareth R. (1995). Strategic Management: An Knoontz O’Donnell Welhrich. (2014). Principles of Management: McGraw-Hill.

[34]. Kotter, John P., \& Cohen, Dan.J. (2002). The Heart of change. Real-life stories of how people change their organizations. Boston Hills. Massachusetts: Harvard Business School Press.

[35]. Kotter, John P. (1996). Leading Change. Boston: HBS.

[36]. Kitty O. Locker. (2010). Business communication: McGraw Hill.

[37]. Kathryn M. Bartol. (1989). Management: McGraw Hill.

[38]. Laudon C. Kenneth and Laudon P. Jane. (2004). Management Information Integrated Approach (3 ${ }^{\text {rded }}$ ): Princeton, New Jersey. Houghton Mifflin Systems. Managing the digital firm. th edition: Pearson Education.Company.

[39]. James A. O’brien. (2004). Management Information Systems: McGraw-Hill/Irwin Jensen Healey. (2001). Effective Performance: Harvard School of Business.

[40]. Joan V. Gallos. (2006). Organizational Development: Jossey - Bass.

[41]. James A.F Stoner. (2009). Management $6^{\text {th }}$ edition .Management Information: Age Publication.

[42]. Lisa Magloff. (2013). Oranizational Change: Grin Publishing. Munich, Germany.

[43]. Luis R. Gomez - Mejia. David B. Balkin. Robert L. Cardy. (2012). Management.

[44]. Publishers: McGraw-Hill Irwin, New York.

[45]. Luis Garicano. (2000). Economics of Organization: Jossey-Bass Publishers Macmillan, P. P. (2001). The performance Factor unlocking the secret of teamwork. Nashville: B \& Publishing

[46]. Knoontz O’Donnell Weihrich. (1986). Essentials of Management: New Delhi

[47]. Knoontz o’Donnell Weihrich. (2011). Management Theory: Southern University Press. Group.

[48]. Mathias, R. L; \& Jackson J.H. (2009). Human Resource Management. Mason. South-Western: Cengage Learning.

[49]. Michael I. Harrison. (1998). Organizational Diagnosis and Assessment: Sage Publications. Thousand Oak, California.

[50]. Mullins Laurice J. (2005). Management and Organization Behaviour: Prentice Hall.

[51]. Nadler-Tushman. (1977). Organization Change Models: Hills Dale. New Jessy.

[52]. Palmer, Dunford \& Akin. (2008). Managing Organizational Change: McGraw-Hill.

[53]. Patrick H. Dessein, Milton Haris \& Artur Raviv. (2002). Organization Design: University of Chicago Library.

[54]. Pearce \& Robinson. (2005). Strategic Management; Formulation, Implementation, and Control. $4^{\text {th }}$ ed: McGrawHill Irwin.

[55]. Peter Davis. (2004). Human Resource Management in Co-operatives. Theory, Process and Practice: ILO Geneva.

[56]. Porras, J.I. (1987). Stream Analysis: A powerful way to Diagnose and Manage Organizational change.Reading Massachusetts: Addison - Wesley.

[57]. Richard L. Daft. (2004). Organizational Behaviour $6^{\text {th }}$ edition: Thomas South- West Mason.

[58]. Robert Kreither, BerryL.Reece; James P.O’grady. (1990). Business: Sage Publishers Robert Kreither. (1991). Management: Houghton Mifflin Company. USA.

[59]. Robert Milgro. John Robert. (1992). Organization and Management: Prentice Hall.

[60]. Rothwell W. J. Starros J.M \& Sullivan A. (2010). Practicing Organization Development. San Francisco: Pffeiffer

[61]. Rosabeth Moss Kanter. (1997). Organization Development: New York Free Press.

[62]. Senge Peter (1994), Kleiner, Art., Roberts, Charlotte., Ross, Richard. B., \& Smith, Bryan.J. (1994).The fifth Discipline field book strategies \& tools for building a learning Organization: New york Double day.

[63]. Schein, E. Kurt Lewin's. (1989, 2010). Organizational Change. Organizational

[64]. Development Approach: South Western Publishing.

[65]. Silberman, Mel .(2003). The Consultant's Big Book of Organizational Development Tools. New York: MCGraw Hill.

[66]. Silberman, Mel. (2003). The Consultant's Big Book of reproducible surveys and Questionnaires. New York: MC Graw Hill.

[67]. Susan S. Raines. (2013). Conflict Management for Managers. Resolving Workplace, client and policy disputes: Jossey-Bass. 
[68]. Tomas D. Andres. (2001). Enhancing Organizational performance and Productivity: New Day. Philippines.

[69]. Vall. M. (2000). Performance Management: Sage Publications.

[70]. Verma \& Beerd. (1981). Organizational Capacities: Martinus Nijhoff publishers.

[71]. Warner Burke. (2006). Organizational Change: MCSER Publishing.

[72]. W. Warner Burke (1982). Organizational Change: Sage Publishes.

[73]. W. Warner Burke, Dale G. Lake and Jill Waymire Paine. (2009). Organization Change: A Comprehensive Reader.

[74]. Yourdon, E. (1989). Modern Structured Analysis. Englewood Cliffs. NJ: Yourdon Press. Unpublished Work

[75]. Chanchai Lawonk. (2008). Organization Development Intervention of Lecturing at the faculty of humanities \& Social Sciences in UdonThani Rajabhat University. Thailand.

\section{Journals/Published Articles:}

[76]. Anthony M. Marino, John G. Matsusaka \& Jan Zabojnik . (2006). Disobedience and Authority, working papers. 1109, Queen's University, Department of Sciences Oxford University Press, Vol, 26 (3) pages 427-459.

[77]. Susman, Gerald I. and Roger D. Evered. (1978). "An Assessment of the Scientific Merits of Action Research". Administrative Science Quaterly, Vol.23, No 4. Johnson Grauate School of Management, Cornell University.

[78]. The Boston Consulting. (2011) High Performance Organizations: The Secrets of their Success. The Boston Consulting Group.

[79]. James P.Spradley. (2000). Qualitative Research and Academy of Management Journal: Academy of Management.

\section{Unpublished Thesis :}

[80]. Apichat Dumdee. (2009). Organization Development Intervention on Team performance of officers at Krasaebon Sub-district Administrative organization in Rayong, Thailand.

[81]. Bautista C.M.B. (2014). Organization Development Intervention on the Performance culture of the word \& Life Publications (WLP), Makati, City, Philippines.

[82]. Esther Njoki Gicheru. (2009). Organization Development Intervention on the workers' performance in the Cooperative College of Kenya, Nairobi, Kenya, East Africa.

[83]. James Kiarie Kuria. (2013). Strategic Management Interventions on the Organizational Systems of Gospel Fire International (GFI) - Africa at Eldoret, Kenya.

[84]. John Ondigo Onsati. (2011). Organization Development Interventions of Team Values on the Performance of Leaders in Nyeri Technical Training Institute, Kenya. Suthon Inthara kamnoet.(2009).

[85]. Organization Development Intervention on peak performance among workers at Capital Cambal Co. Ltd in Ayuttaya Province. Thailand.

[86]. ThastchaiLiam thaisong. (2007). Organizational Development Intervention of Liam Thai marketing Company Ltd in Samutsakhon. Thailand. 